Ethiopian Journal of Environmental Studies \& Management 7 Suppl.: 832 - 839, 2014.

ISSN:1998-0507

doi: http://dx.doi.org/10.4314/ejesm.v7i2.3S

Submitted: September 17, 2014

Accepted: November 17, 2014

\title{
FARMERS' PERCEPTION AND ADAPTATION TO CLIMATE CHANGE: HECKMAN'S TWO STAGE SAMPLE SELECTION MODEL
}

\author{
*URGESSA TILAHUN ${ }^{1}$ AND AMSALU BEDEMO ${ }^{2}$ \\ ${ }^{1}$ Haro Sabu Agricultural Research Center, P.O.Box 10, Dale Sadi, Kellem Wollega, Ethiopia \\ ${ }^{2}$ Assosa University, P.O.Box 018, Asossa, Ethiopia
}

\begin{abstract}
This study examines farmers' perception and adaptation to climate change in Guto Gidda and Sasigga districts of Oromia Regional National State in Ethiopia. Primary data for the study were collected from 142 farm household heads drawn from five kebeles of Sasiga district and four kebeles of Guto Gida district through structured questionnaire. Heckman two stage sample selection model was employed to examine farmers' perception and adaptation strategies to climate change. Estimation result shows that farmers level of education $(p=0.040)$, household nonfarm income $(p=0.030)$, livestock ownership (0.001), extension on crop and livestock $(p=0.000)$, household's credit accessibility $(p=0.001)$, perception of increase in temperature $(p=0.000)$ and perception of decrease in precipitation $(p=0.000)$ significantly affect the adaptation to climate change. Similarly, farmers' perception of climate change was affected significantly by information on climate $(p=0.000)$, farmer to farmer extension $(p=0.009)$, local agro l-ecology $(p=0.002)$, number of relatives in development group $(p=0.015)$ and perception of change in duration of season ( $p=0.002)$.
\end{abstract}

Key Words: Climate Change, East Wollega, Western Ethiopia

\section{Introduction}

Ethiopia, one of the developing countries, is facing serious natural resource degradation problems (Anemut, 2006). The diversity in altitude accompanied with climatic and ecological variations which affect production is among the features of the country (Shibru and Kifle, 1998). One of Ethiopia's principal natural resources is its rich endowment of agricultural land. Agriculture is the backbone of the Ethiopian economy and is given special attention by the government to spearhead the economic transformation of the country. However, land degradation, especially soil erosion, soil nutrient depletion and soil moisture stress, is a major problem confronting Ethiopia. The proximate causes of land degradation include cultivation of steep slopes and erodible soils, low vegetation cover of the soil, burning of dung and crop residues, declining fallow periods, and limited application of organic or inorganic fertilizers.

Climate is a primary determinant of agricultural productivity (Apata et al., 2009). The rate and magnitude of change in climate characteristics determines agronomic and economic impacts from climate change (Bruce et al., 2001). Though climate change is a threat to agriculture and non-agricultural socio-economic development, agricultural production activities are generally more vulnerable to climate change than other sectors (Ayanwuyi et al., 2010). The purpose of this study is therefore, to examine the farmers' perceptions and adaptation to

*Corresponding Author: Urgessa Tilahun 
Farmers' Perception and Adaptation to Climate Change................URGESSA \& AMSALU

climate change, measures taken by farmers in adapting climate change and causes of non adaptation in climate change.

\section{Description of the Study Area}

Guto Gida is among the 17 districts of East Wollega Zone that has 21 farmers associations and 1 urban center possessing a total area of $901.80 \mathrm{~km}^{2}$. It is contiguous with Gidda Ayyana, Abe Dongoro and Gudaya Bila through the North, Sibu Sire and Wayyu Tuka through the East, Leka Dulecha through the south and Digga, Sasiga and Benshengul Gumuz Regional State through the west (GGDFEDO, 2011).

Sasiga district is also found in East Wollega Zone. It is located at about 18 kilometers west of Nekemte town, zonal town, possessing a total area of $980.70 \mathrm{~km}^{2}$. This district is contiguous with Benshengul Gumuz Regional State in the North and West, Digga district in the south, and Guto Gida district in the east. It is divided in to 27 farmers associations and one urban center having the capital town named Gallo (SDFEDO, 2011).

\section{Climate}

Climate is the long-term effect of the sun's radiation on the rotating earth's varied surface and atmosphere. Agroecological zones are areas where predominant physical conditions guide relatively homogeneous agricultural land use options. Because of Ethiopia's location near the equator, elevation has very strong influence on temperature and, to lesser extent, on rainfall. Elevation is the basis for traditional agroecological divisions, which have long been used to characterize different environments in Ethiopia (CSA and IFPRI, 2011). Climate can be understood most easily in terms of annual or seasonal averages of temperature and precipitation. Guto Gida district is situated between altitude of 1,350 to 2,450 meters above sea level which reflects the existence of three agro-ecological zones i.e. Kolla, Woina Dega and Dega. As a result this area is experienced mean annual temperature of slightly greater than $15^{\circ} \mathrm{c}$ and mean annual rainfall of $1,600 \mathrm{~mm}$ to 2,000 $\mathrm{mm}$ (GGDFEDO, 2011). Most part of the land of Sasiga district has an elevation above 1000 meters and characterized by sub tropical climatic condition with a mean annual temperature between $26.5^{\circ} \mathrm{C}$ and $27^{\circ} \mathrm{C}$ and mean annual rainfall of $800 \mathrm{~mm}$ to 1,200 mm (SDFEDO, 2011).

\section{Methodology \\ Sampling Procedure}

This paper used both primary and secondary data. Primary data was collected by structured questionnaire. Detailed information on household and farm characteristics, household socio-economic and demographic characteristics, location characteristics and farm management practices and other related information were collected through interview of sample household heads.

The study was conducted in Guto Gida and Sasiga districts, East Wollega Zone of Oromia Regional State. These districts were purposefully selected due to the fact that in these areas the environment has been degraded largely and the occurrence of climate change that affect agricultural production during the year 2010 and 2011 in three kebeles of Guto Gida district.

Systematic random sampling technique was employed to draw sample of household heads. From a total of 50 peasant associations in these districts nine peasant associations were selected randomly. From these sampled peasant associations based on formula by Kothari (2004) 142 households were selected proportionally. 




Source: East Wollega Zone Finance and Economic Development Office (2013)

Figure 1: Map of the study area

\section{Econometric Model}

Adaptation to climate change involves a two-stage process: first, perceiving change and, second, deciding whether or not to adapt by taking a particular measure. This leads to a sample selectivity problem, since only those who perceive climate change will adapt, whereas we need to make an inference about adaptation by the agricultural population in general, which implies the use of Heckman's sample selectivity model
(Maddison, 2006). The model for sample selection assumes that an underlying relationship exists, the latent equation given by

$$
y_{j}^{*}=x_{j} \beta+u_{1 j}
$$

such that we observe only the binary outcome given by the probit model as

$$
y_{j}^{\text {probit }}=\left(y_{j}^{*}>0\right)
$$


The dependent variable is observed only if $\mathrm{j}$ is observed in the selection equation

$$
\begin{aligned}
& y_{j}^{\text {select }}=\left(z_{j} \delta+u_{2 j}>0\right) \\
& u_{1} \sim N(0,1) \\
& u_{2} \sim N(0,1) \\
& \operatorname{corr}\left(u_{1}, u_{2}\right)=\rho
\end{aligned}
$$

Where $\mathrm{x}$ is a k-vector of regressors or independent variables that is affect farmers perception and adaptation to climate change, $\mathrm{z}$ is an $\mathrm{m}$ vector of regressors, $\mathrm{u}_{1}$ and $\mathrm{u}_{2}$ are error terms. When $\rho \neq 0$, the standard probit techniques applied to equation (1) yield biased results (Deressa et al., 2008). Thus, the Heckman probit provides consistent, asymptotically efficient estimates for all parameters in such models. Thus, the Heckman two stage selection model was employed to analyze the perception and adaptation to climate change in the Guto Gida and Sasiga districts.

For this study, the first stage of the Heckman probit model considers whether the farmer perceived a climate change; this is the selection model. The second-stage model looks at whether the farmer tried to adapt to climate change, and it is conditional on the first stage, that is, a perceived change in climate. This second stage is the outcome model (Deressa et al., 2008).

\section{Variables used in the analysis}

The explanatory variables for the selection equation include different sociodemographic and environmental factors based on the literature on factors affecting the awareness of farmers to climate change or their risk perceptions. The variables included in the analysis are level of education, farmers information on climate change, farmer to farmer extension, household's number of relatives in development group, household farm income, total family size, sex of household, household non-farm income, household's livestock ownership, extension on crop and livestock, household's credit availability, farm size in hectares, distance to input market, distance to output market, local agro ecology, increase in temperature, decrease in temperature, no change in temperature, increase in precipitation, decrease in precipitation, and no change in precipitation.

\section{Results and Discussions}

\section{Farmers' Perception and Adaptation to Climate Change}

Adaptation to climate change is a twostep process which requires that farmers perceive climate change in the first step and respond to changes in the second step through adaptation. The analysis of farmers' perceptions of climate change indicates that most of the farmers in this study are aware of the fact that temperature is increasing and the level of precipitation is declining (Table 1). Different socio-economic and environmental

\begin{tabular}{|c|c|c|c|c|c|c|}
\hline \multirow[t]{3}{*}{ List of variables } & \multicolumn{4}{|c|}{ Districts } & \multirow{3}{*}{$\begin{array}{l}\text { Total } \\
\text { No }\end{array}$} & \multirow[b]{3}{*}{ Yes } \\
\hline & \multicolumn{2}{|c|}{ Guto Gida } & \multicolumn{2}{|c|}{ Sasiga } & & \\
\hline & No & Yes & No & Yes & & \\
\hline Increase_Temperature & 18 & 51 & 31 & 42 & 49 & 93 \\
\hline Decrease_Temperature & 68 & 1 & 67 & 6 & 135 & 7 \\
\hline Nochange_Temperature & 66 & 3 & 67 & 6 & 133 & 9 \\
\hline Decrease_Precipitation & 28 & 41 & 24 & 49 & 52 & 90 \\
\hline Increase_Precipitation & 60 & 9 & 71 & 2 & 131 & 11 \\
\hline Nochange_Precipitation & 64 & 5 & 70 & 3 & 134 & 8 \\
\hline
\end{tabular}
factors affect the abilities to perceive and adapt to climate change.

Table 1: Farmers Perception of Change in temperature and precipitation 
Among the explanatory variables used in the model, 7 variables were significant with respect to outcome equation with less than 10 percent of the probability level while 5 variables were significant with respect to selection equation (Table 2). The variables having a significant effect on adaptation to climate change in the study area are discussed below.

Table 2: Result of Heckman two stage sample selection model $(\mathrm{n}=142)$

\begin{tabular}{|c|c|c|c|c|c|}
\hline $\begin{array}{l}\text { Farmers' Perception to } \\
\text { equation) }\end{array}$ & Climate $\mathrm{C}$ & (Selection & $\begin{array}{l}\text { Farmers' Adaptation } \\
\text { (Outcome equation) }\end{array}$ & Clim & Change \\
\hline \multirow{2}{*}{ List of variables } & \multicolumn{2}{|c|}{ Marginal Effect } & \multirow{2}{*}{ List of variables } & \multicolumn{2}{|c|}{ Marginal Effect } \\
\hline & $\mathrm{dy} / \mathrm{dx}$ & $\mathrm{P}$-value & & $\mathrm{dy} / \mathrm{dx}$ & $\mathrm{P}$-value \\
\hline Education & 0.00349 & 0.180 & Education & 0.03757 & $0.040 * *$ \\
\hline Sex & 0.04491 & 0.265 & Family_Size & 0.01327 & 0.152 \\
\hline No_of_relatives & 0.00160 & $0.015 * *$ & Sex & 0.00286 & 0.965 \\
\hline Farm income & 0.00000 & 0.802 & Non-Farm Income & 0.00001 & $0.030 * *$ \\
\hline Local agroeco & -0.16196 & $0.002 * * *$ & Livestock_Ownership & 0.19014 & $0.001 * * *$ \\
\hline Information & 0.18417 & $0.000 * * *$ & Extension_on_Crop & 0.20033 & $0.000 * * *$ \\
\hline Season_change & 0.03442 & $0.002 * * *$ & Credit & 0.12781 & $0.001 * * *$ \\
\hline Farmer_extension & 0.50799 & $0.009 * * *$ & Farm_Size & -0.01752 & 0.337 \\
\hline Distance_Input & & & & 0.00153 & 0.580 \\
\hline Distance_Output & & & & 0.00153 & 0.431 \\
\hline Increase_Temperature & & & & 0.42288 & $0.000 * * *$ \\
\hline Decrease_Temperature & & & & 0.13554 & 0.190 \\
\hline Decrease_precipitation & & & & 0.64763 & $0.000 * * *$ \\
\hline District & -0.10635 & $0.036 * *$ & & -0.08341 & 0.233 \\
\hline
\end{tabular}

$* * *, * *$ and $*$ significant at $1 \%, 5 \%$ and $10 \%$ level respectively.

The number of relatives is one of the social capitals which increase the awareness of the households on their environment. As expected, households' number of relatives in development group was positively related with perception of climate change. One increase in number of relative of household head raises the probability of perceiving climate change by 0.16 percent.

Having access to farmer to farmer extension increases the likelihood of perceiving occurrence of climate change by 50.79 percent. Information on temperature and rainfall has a significant and positive impact on the likelihood perceiving climate change and access to information on climate change increases the probability of perceiving the occurrence of change in climate by 18.42 percent. Access to climate change Information is an important precondition for farmers to take up adaptation measures (Maddison, 2006).

The agro-ecological setting of farmers influences the perception of farmers to climate change. As expected, different farmers living in different agro-ecological settings perceive the occurrence of climate change differently. The result of this study shows as one moves from Kolla to Woina dega local agro-ecology the probability of perceiving the occurrence of climate change decreases by 16.19 percent. Contrary to Deressa et al., (2011) farmers living in Kolla (lowland) perceived more change in climate than farmers in Woina dega (mid-land) or Dega (high land).

The farmers' perception of change in duration of season significantly affects perception of climate change. As an individual farmer observe change in duration of season, his/her probability of perceiving 
change in climate increases by 3.44 percent. District dummy variable negatively and significantly affected perception of climate change. This shows that respondent households in Guto Gida district perceived the occurrence of climate change than those in Sasiga district.

Level of education of household took the expected sign and its coefficient was significant at less than 10 percent probability level. It had a positive and strong relationship with the dependent variable showing that literate household heads were more probability to adapt climate change on average. One level increase in education raises the probability of adaptation to climate change by 3.75 percent. This result is in line with Ayanwuyi et al. (2010) who reported that education level of households had positive and significant relationship with perception of climate change.

Nonfarm income increases the probability of adapting the climate change. One birr increase in household nonfarm income leads to the increment of the probability of adaptation to climate change by 0.001 percent. This implies that households with income may get capital, land and labour. These factors serve as important factors for coping with adaptation (Apata et al., 2009). So, adaptation to climate change depends on availability of income.

Livestock ownership is a sign of wealth to farmers (Sofoluwe et al., 2011). The ownership of livestock is also positively related to the adaptation of climate change. An increase in access to livestock ownership raises the probability of adaptation to change in climate by 19.01 percent.

As expected, access to crop and livestock extension has a positive and significant impact on adaptation to climate change. Having access to crop and livestock production increases the probability of adapting climate change by 20.03 percent. This result is in line with Ayanwuyi et al.
(2010) who reported that access to extension facilities of households had positive and significant relationship with perception and adaptation of climate change.

Resource availability is generally expected to positively influence farmers' to adapt climate change. Hence, access to credit is expected to have positive relationship with farmers' adaptation to change in climate. Credit availability is one factor that leads household to adapt climate change. An increase in access to credit raises the probability of adaptation to climate change by 12.78 percent. Similar with this finding Charles and Rashid (2007) and Apata et al. (2009) showed farmers with access to credit have higher chances of adapting to changing climatic conditions. This result is also in line with Ayanwuyi et al. (2010) who reported that access to credit facilities of households had positive and significant relationship with perception of climate change and adaptation options.

Increment in temperature and adaptation to climate change were hypothesized to be related positively. As expected the result of this study shows the direct relationship between adaptation to climate change and perception of increase in temperature. Perceived change in temperature has significant effect in the likelihood of employing climate change adaptation strategies (ACCCA, 2010). For increment in perception of increase in temperature raises the probability of adaptation to climate change by 42.28 percent. Adaptation to climate change and precipitation were negatively related as expected. Perceiving decrease in precipitation raises the probability of adapting climate change by 64.76 percent.

\section{Climate Change Adaptation Measures and Causes of Non Adaptation}

From all respondents who adapted the change in climate majority of them (45.33 percent) adapted the change through taking 
soil conservation measures. About 9.33 percent have taken measures of planting crop varieties in order to cope up climate change problem. 32 percent of them were participated on planting trees in reducing the problem caused by climate change. The remaining 13.34 percent of total households who adapted the change in climate were participated in irrigation activities in order to solve problem faced them through climate change.

Out of all respondent households who perceived the change in climate, those who did not adapt the change was not free of cause. Majority of them (47 percent) did not adapt because of shortage of labor while 32 percent of them did not adapt the change in climate because of lack of money to undertake the adaptation measures. From all those who did not adapt the change in climate 12 percent of them were absent from adapting the change because of lack of information and poor potential for irrigation.

\section{Conclusion and Policy Implications}

This study examined factors that influence farmer's perception and adaptation to climate change and used Heckman two stage sample selection model to identify the significant variables.

Farmers level of education, household nonfarm income, livestock ownership, extension on crop and livestock, household's credit availability, perception of increase in temperature and perception of decrease in precipitation were those variables which significantly affect the adaptation to climate change. Similarly, the farmers' perception of climate change was affected significantly by information on climate, farmer to farmer extension, local agro-ecology, number of relatives in development group and perception of change in duration of season.

Farmer's access to crop and livestock extension is positively and significantly affects adaptation to climate change. This shows farmers with best access to crop and livestock extension adapt the impact of climate change more. Therefore, the government and policy makers should encourage the way farmers get extension on crop and livestock than ever in order to increase the farmer's adaptability of climate change.

The availability of resource affects farmers to adapt to climate change. The result of this research shows that availability of credit affect adaptation to climate change positively and significantly. So, the government and policy makers should respond to the way through which farmers get best access to credit and other resources from different saving and credit institutions to increase their way of adaptation to climate change.

Accessibility of information on climate change is necessary for the perception of climate change. Farmers with best accessibility of information on climate change perceive the occurrence of climate change than those without the accessibility of the information. Therefore, the local government, NGOs and policy makers should focus on the way farmers get more accessibility of information on climate change.

\section{Acknowledgments}

The authors thank the editor and anonymous reviewers of this journal for their helpful comments and suggestions on an earlier version of this manuscript.

\section{References}

ACCCA. (2010). Improving decision-making capacity of small holder farmers in response to climate risk adaptation in three drought-prone districts of Tigray, northern Ethiopia, Mekelle, Ethiopia

Anemut, B. (2006). Determinants of Farmers' Willingness to Pay for the Conservation of National Parks: The 
Case of Simen Mountains National Park, MSc Thesis in Agricultural Economics, Haramaya University

Apata, T.G., Samuel, K.D. and Adeola, A.O. (2009). Analysis of Climate Change Perception and Adaptation among Arable Food Crop Farmers in South Western Nigeria, International Association of Agricultural Economists' 2009 Conference, Beijing, China

Ayanwuyi, E. Kuponiyi, F.A., Ogunlade, and Oyetoro, J. (2010). Farmers Perception of Impact of Climate Changes on Food Crop Production in Ogbomosho Agricultural Zone of Oyo State, Nigeria, Global Journal of Human Social Science, 10(7): 33-39

Bruce, A.M., Richard, M.A., and Brian, H. H. (2001). Global Climate Change and Its Impact on Agriculture

Charles, N. and Rashid, H. (2007). MicroLevel Analysis of Farmers' Adaptation to Climate Change in Southern Africa, IFPRI Discussion Paper 00714.

CSA and IFPRI. (2011). Atlas of Agricultural Statistics, 2006/07-2010/11, Addis Ababa, Ethiopia

Deressa, T.T., Hassan, R.M., and Ringler, C. (2011). Perception of and adaptation to climate change by farmers in the Nile basin of Ethiopia, Journal of Agricultural Science, 149: 23-31

Deressa, T.T., Hassan, R.M. Tekie, A., Mahmud, Y. and Claudia, R. (2008).
Analyzing the Determinants of Farmers' Choice of Adaptation Methods and Perceptions of Climate Change in the Nile Basin of Ethiopia GGDFEDO. (2011). Physical and SocioEconomic Profile of Guto Gida District

Kothari, C.R. (2004). Research Methodology; Methods and Techniques, 2nd Revised Edition, New Age International Publishers, New Delhi, India

Maddison, D. (2006). The Perception of and Adaptation to Climate Change in Africa, CEEPA Discussion Paper No.10, Centre for Environmental Economics and Policy in Africa, University of Pretoria.

Shibru, T. and Kifle, L. (1998). Environmental Management in Ethiopia: Have the National Conservation Plans Worrked? Organization for Social Science Research in Eastern and Southern Africa (OSSREA), Addis Ababa, Ethiopia

Sofoluwe, N.A., Tijani, A.A. and Baruwa, O.I. (2011). Farmers' perception and adaptation to climate change in Osun State, Nigeria, African Journal of Agricultural Research, 6(20): 47894794

SDFEDO. (2011). Physical and SocioEconomic Profile of Sasiga District 